\title{
Materials Education 2003 Topical Trends and Outreach Efforts
}

\author{
Craig Johnson, Mark Palmer
}

\author{
Central Washington University / Kettering University
}

\begin{abstract}
This research explores the history of topical trends in the ASEE Materials Division. This history will be compared with national trends. It is observed that creative materials education efforts in non-major curricula are highly sought, following national trends of higher contact numbers of students in related engineering programs vs. relatively small numbers of students in materials programs. Issues of implementing laboratory curricula reflect the increasing attention to safety and liability concerns. Every year, at least one topic has been multi-disciplinary and cosponsored with another division.
\end{abstract}

Analysis of other efforts in Materials Education will be presented, along with any interaction the ASEE Materials Division has with these efforts. Specific mention will be made of efforts by TMS. TMS has materials education efforts, and it disseminates information through respective meetings and publications. Thus far, efforts of these organizations have been independent and compartmental.

The data presented in this study will be used during the business meeting to generate discussion and selection of future materials division session topics. It will also be used as a focus for a discussion on any outreach efforts that the materials division may enact.

Introduction

American Society for Engineering Education (ASEE) has a mission to support engineering education both internally and externally. An external aspect may include joint sponsorship of an appropriate conference, or the support of internships with the National Aeronautics and Space Administration. Internal ASEE efforts may include relevant articles in the organization's journal (PRISM) and the annual conference. ASEE is structured with 'divisions' (by topic) that sponsor a portion of the annual conference. This internal engineering education effort is subsequently described.

American Society for Engineering Education Divisions has the responsibility of supporting the organizations efforts in their discipline. This includes publishing 'requests for papers' in the summer PRISM journal issue, and implementing the paper acceptance, review and presentation policies for the annual conference. This effort is done within the divisions, with little interaction (within or between the divisions). Also, typical division by-laws result in regular turn-over of officers. This is reflected in limited awareness of what session topics have been presented in the past.

"Proceedings of the 2002 American Society for Engineering Education Annual Conference \& Exposition Copyright $@$ 2002, American Society for Engineering Education” 
The Materials Division is relatively small and has not kept a history of its efforts in newsletter, website or other 'corporate memory' format. A record of session topics in particular would be of value to the division officers ${ }^{1}$.

Beyond the internal responsibilities, the division could benefit from (and involvement with) external efforts in materials education. Some on-going efforts include our support of the annual 'National Educators' Workshop' ${ }^{2}$ (NEW). Other efforts in materials education are founded in our peer organizations such as TMS and MRS.

\section{ASEE Materials Division Efforts}

The Materials Division has hosted sessions for three decades. Session information for the last five years has been tabulated below $3,4,5,6$ :

\begin{tabular}{|c|c|c|c|}
\hline Session \# & ASEE 1999 DESCRIPTION ${ }^{3}$ : & \# Abs (25) & \# PAPERS \\
\hline 0564 & NEW Experiments & & 7 \\
\hline 1364 & Matl's Eng. In the Real World & & 3 \\
\hline 1464 & ABET 2000 for Matl's Eng. & & 1 \\
\hline 1564 & Matl's Division Poster Session & & Cancelled \\
\hline 1664 & Active Learning in Matl's Educ. & & 4 \\
\hline 2564 & Establishing Objectives for Mat'ls & & Workshop \\
\hline 2764 & Materials Division Dinner & & NA \\
\hline 3264 & Innovative Matl's Experiments & & 3 \\
\hline 3464 & Materials Div. Business Mtg. & & NA \\
\hline
\end{tabular}

\begin{tabular}{|c|c|c|c|}
\hline Session \# & ASEE 2000 DESCRIPTION ${ }^{4}$ : & \# Abs (30) & \# PAPERS \\
\hline 1464 & Matl's Design and Mech Behavior & & 5 \\
\hline 2464 & Innovations in Matl's Curricula & & 5 \\
\hline 2664 & Materials Div. Business Meeting & & NA \\
\hline 2764 & Materials Div. Get-together & & NA \\
\hline 3264 & NEW:A Picture Says 1000 Words & & 7 \\
\hline 3464 & Materials is More than Metals & & 5 \\
\hline 3664 & Active Learning in Materials Sci & & 5 \\
\hline
\end{tabular}

\begin{tabular}{|l|l|l|l|}
\hline Session \# & ASEE 2001 DESCRIPTION & \# Abs (25) & \# PAPERS \\
\hline 1464 & Teaching Fracture and Failure & & 5 \\
\hline 1664 & Intro. Materials Experiences & & 5 \\
\hline 1764 & Matl's Division Get-together & & NA \\
\hline 2264 & Matl's Div. Business Meeting & & NA \\
\hline
\end{tabular}




\begin{tabular}{|l|l|l|l|}
\hline 2464 & Integration with Other Curricula & & 5 \\
\hline 3264 & NEW: 2000 Update & 8 \\
\hline 3464 & Upper-Level Courses \& New & & 5 \\
\hline
\end{tabular}

\begin{tabular}{|l|l|l|l|}
\hline Session \# & ASEE 2002 DESCRIPTION & \# Abs (48) & \# PAPERS \\
\hline 1464 & Modeling in Matl's Education & & 5 \\
\hline 2264 & Matl's Div. Business Meeting & & NA \\
\hline 2364 & Teaching Matl's to Non-Majors & & NA \\
\hline 2464 & Teaching Ceramics, Polymers \& & & 3 \\
\hline 3064 & NEW: Experiment Set-up & & NA \\
\hline 3264 & NEW: Matl's Lab Experiments & & 8 \\
\hline 3464 & Materials \& Mech. Engineering & & 3 \\
\hline
\end{tabular}

\begin{tabular}{|c|c|c|c|}
\hline Session \# & ASEE 2003 DESCRIPTION ${ }^{6}$ : & \# Abs (31) & \# PAPERS \\
\hline 1464 & Demos \& Labs in Matl's Educ & & 5 \\
\hline 2164 & K-20 Activities in Matl's Educ & & 6 \\
\hline 2264 & Matl's Div. Business Meeting & & NA \\
\hline 2464 & Modeling and Math in Matl's & & 6 \\
\hline 3164 & NEW: Experiment Set-up & & NA \\
\hline 3264 & NEW: Matl's Lab Experiments & & 8 \\
\hline 3464 & Diversity in Courses and Matl's & & 5 \\
\hline NONE & Life Cycle Analysis:no abstracts & & 0 \\
\hline
\end{tabular}

A number of statistics may be of use for planning purposes. The topics themselves are of interest, as well as how many abstracts were submitted. Attendance figures have not yet been acquired.

Activities, laboratories and experiments of various sorts appear as a mainstay over the years. These efforts are above and beyond our interaction with NEW. These experiments have been focused by education level (K-12, K-20, lower div., upper div.), but have appeared in all four years.

Curricula development has appeared regularly. Some of this has been oriented toward accreditation, but most is of a general nature (e.g. 'materials curricula').

Teaching methods is also a common topic. This is folded into curricula development in some cases, or even the 'Activities' category. However, it is has a specific meaning and was responsible for a sizable number of abstracts in 2002.

There have also been 'alternate materials' of various titles through the years. These include: 
'more than metals' and ceramics, polymers and electronics materials'.

Special topics have surfaced over the years. These include 'Failure Analysis', 'materials and mechanical engineering', and an attempt to create a session on Life Cycle Analysis.

A last observation is that of 'modeling and design' in materials. With the computational resources available, more interest and activity is occurring in modeling of materials systems. The resulting ability to design with respect to materials is reflected in more abstract submissions.

\section{External Materials Education Efforts}

Our closest external education effort has been the ASEE Materials Division's continued support of the National Educators' Workshop. A number of individuals are selected to represent the annual National Educators' Workshop efforts in the field of education. An entire ASEE session is devoted to NEW.

In a broader sense, ASEE has international outreach efforts. ASEE has co-sponsored conferences in Europe, and opportunities may exist for specific endeavors in materials education.

In a closer view, there should be synergy in related organizations such as TMS, ASM and MRS. The Minerals, Metals \& Materials Society (TMS) ${ }^{7}$ has a mission statement that reads: "Promoting the global science and engineering professions concerned with minerals, metals and materials." It supports a journal (JOM), a number of conferences and other endeavors. It also has an education committee with an appropriate mission. There is little interaction, however, between the different organizations.

A partial list of materials education organizations is shown in the following table. Some efforts of these organizations are discussed in the paragraphs following the table.

\begin{tabular}{|l|l|l|}
\hline Organization & Discipline & Contact \\
\hline $\begin{array}{l}\text { American Society for Engineering } \\
\text { Education, Materials Division }\end{array}$ & Materials Education & www.asee.org \\
\hline ASM International & $\begin{array}{l}\text { Materials Industry } \\
\text { Information Promotion }\end{array}$ & www.asm-intl.org \\
\hline $\begin{array}{l}\text { TMS-AIME (The Minerals, Metals } \\
\& \text { Materials Society) }\end{array}$ & Education Committee & www.tms.org \\
\hline MRS (Materials Research Society) & & www.mrs.org \\
\hline AcerS (American Ceramic Society) & $\begin{array}{l}\text { Materials Division } \\
\text { ASME (American Society of } \\
\text { Mechanical Engineers) }\end{array}$ & www.acers.org \\
\hline $\begin{array}{l}\text { Smithsonian Institution } \\
\text { Research and Education }\end{array}$ & www.si.edu \\
\hline
\end{tabular}

"Proceedings of the 2003 American Society for Engineering Education Annual Conference \& Exposition Copyright $@$ 2003, American Society for Engineering Education” 
A major disseminator of materials information is ASM International ${ }^{8}$ (The Materials Information Society). This organization offers publications, courses, conferences and other venues such as local chapters. It's mission reads: "ASM International is the society for materials engineers, a worldwide network dedicated to advancing industry, technology and applications of metals and materials. Through the efforts and involvement of our members, ASM develops and distributes timely, reliable technical information through electronic media, publications, conferences training programs, and chapter activities." ASM and TMS have recently co-sponsored some conferences.

The Materials Research Society (MRS) is "a non-profit organization which brings together scientists, engineers and research managers from industry, government, academia and research laboratories to share findings in the research and development of new materials of technological importance." It has the conventional structure including a journal, conferences and chapters. There is an Academic Affairs Committee, but no education specific committee shown on their web site.

The American Ceramics Society ${ }^{10}$ (ACERS) "is an international association that provides the latest technical, scientific and educational information to its Members and others in the ceramics and related materials field, structures its services, staff and capabilities to meet the needs of the ceramics community, related fields, and the general public." ACERS has an education council and a visible outreach effort covering K-20.

The American Society of Mechanical Engineers ${ }^{11}$ (ASME) has a Materials Division and a Journal of Engineering Materials and Technology. ASME has various educational forums (conferences, courses, etc.), coordinated through their Continuing Education Institute and Educational Services.

There are also numerous government efforts related to materials education. Since materials as a field supports many industries, examples are varied in scope and depth. The National Science Foundation (NSF) has 'Centers' at universities related to various aspects of materials. There are similar Department of Defense (DOD) efforts (e.g. \$0.5M Edmunds Community College Materials Science Technology Program) $)^{12}$.

Summary and Future Plans

Four years of ASEE Materials Division information has been presented. It was observed that internal annual conference efforts to promote materials education have typically focused on improved curricula. However, specific areas of interest include; curricula development, teaching materials to non-majors and 'activities' of various types.

Entities with similar materials education missions have been identified. Some information has been exchanged with the education committee of TMS.

This document is offered as a living 'corporate memory' of the ASEE Materials Division. It is intended to be used at the division business meeting for planning purposes.

"Proceedings of the 2003 American Society for Engineering Education Annual Conference \& Exposition Copyright $@$ 2003, American Society for Engineering Education” 


\section{Acknowledgements}

Thanks to Central Washington University, it's College of Education and Professional Studies, and it's Department of Industrial \& Engineering Technology for continued support of efforts in materials science and engineering education.

Bibliography

1. ASEE Materials Business Meeting, Montreal, Canada, 2002.

2. National Educators' Workshop, http://www.engr.sjsu.edu/cme/NEW/ 2002.

3. ASEE Annual Conference \& Exposition, http://www.asee.org, 1999.

4. ASEE Annual Conference \& Exposition, http://www.asee.org ,2000.

5. ASEE Annual Conference \& Exposition, http://www.asee.org ,2001.

6. ASEE Annual Conference \& Exposition, http://www.asee.org ,2002.

7 The Minerals, Metals \& Materials Society, http://www.tms.org ,2003.

8 The Materials Information Society, http://www.asm-intl.org ,2003

9 The Materials Research Society, http://www.mrs.org ,2003

10 The American Ceramics Society, http://www.acers.org ,2003

11 The American Society of Mechanical Engineering, http://www.asme.org ,2003.

12 Edmunds Community College Press Release, http://highlights.edcc.edu ,2003.

\section{CRAIG JOHNSON}

Craig Johnson is the Coordinator of the Mechanical Engineering Technology Program at Central Wash. Univ. $\mathrm{He}$ is the Foundry Education Foundation Key Professor (www.cwu.edu/ cjohnson) and has a P.E. in Metallurgy. Dr. J. is the ASEE Materials Division Program Chair. He specializes in test design, interface characterization and process optimization (forming \& casting).

\section{MARK PALMER}

Mark is an Assistant Professor of Manufacturing Engineering at Kettering University. He is the ASEE Materials Division Chair and also serves TMS on the Education Committee. 